\title{
Mitä tarkoittaa konvergenssi?
}

Virittäjän numerossa 4/2018 Santeri Junttila arvioi Valter Langin (2018) teosta Läänemeresoome tulemised (Junttila 2018). Sivuilla 604-605 Junttila sanoo Langin esittävän kielen jakautumisen ja sulautumisen yhtä tärkeinä ilmiöinä kielihistoriassa. Sitten hän jatkaa itse, että sulautuminen eli konvergenssi on lähinnä näköharha ja että kritiikki koskee enemmän Langin siteeraamia kielitieteilijöitä kuin Langia itseään.

Lang (2018: 59) viittaa kyseisessä kohdassa teokseeni Suomalaisten esihistoria kielitieteen valossa (Häkkinen 1996). Langin mainitsemassa kohdassa kirjoitan, että kielen kehittyminen ei ole yksioikoista jakautumista ja eriytymistä vaan myös sulautumista ja keskinäistä vuorovaikutusta (mts. 61). Näiden tärkeysjärjestyksestä en sano mitään, kuten ei myöskään Lang. Tässä kohdassa en käytä termiä konvergenssi, eikä sitä käytä myöskään Lang.

Fennougristiikassa termiä konvergenssi on perinteisesti käytetty tarkoittamassa rinnakkaiskehitystä: samat tai samanlaisiin tuloksiin johtavat kehitykset voivat toteutua toisistaan riippumatta usealla eri taholla. Tällä tavalla konvergenssia ovat käyttäneet esimerkiksi Paavo Ravila (1959: 187), Erkki Itkonen (1966: 98-99, 265-266) ja Mikko Korhonen (1993: 203). Tässä merkityksessä olen itsekin käyttänyt termiä puheena olevassa teoksessani, ja tietoisena siitä, että termit ovat usein monitulkintaisia, olen sen määritellytkin sivulla 58 .

Sekä Ravila että Itkonen esittävät edellä mainituissa lähteissä useita esimerkkejä kieliopillisesta konvergenssista suomensukuisten kielten piirissä. Yksi näistä on
*-mpV-tunnuksella muodostetun komparatiivin kehittyminen toisaalta itämerensuomalais-saamelaisiin kieliin, toisaalta unkariin. Tässä tarkoitetun uralilaisen *-mpV-suffiksin historiaa on viimeksi käsitellyt Jussi Ylikoski (2018). Hän kirjoittaa englanniksi ja käyttää termejä convergent development ja convergent comparatives (mas. 49, 51).

Junttila käyttää termiä toisessa merkityksessä kuin ne lähteet, joihin hän itse viittaa, ja antaa samalla virheellisen kuvan siitä, mitä hänen kritisoimissaan lähteissä todella sanotaan. Tällainen menettely on tyypillistä mielipidekirjoituksille, mutta se ei valitettavasti ole ainutlaatuinen poikkeus tieteellisissäkään kirja-arvioissa, kuten käy ilmi esimerkiksi Virittäjässä viime aikoina käydystä keskustelusta (ks. Sarhimaa 2018). Nimenomaan tieteellisellä foorumilla arvostelijan vastuu on suurempi kuin hän ehkä itse aavistaakaan.

\section{KAISA HÄKKINEN etunimi.hakkinen@utu.fi}

Kirjoittaja on suomen kielen emeritaprofessori Turun yliopistossa.

\section{Lähteet}

HÄKKINEN, KAISA 1996: Suomalaisten esihistoria kielitieteen valossa. Tietolipas 147. Helsinki: Suomalaisen Kirjallisuuden Seura.

ITKONEN, ERKKi 1966: Kieli ja sen tutkimus. Porvoo: WSOY.

Junttila, SANTERI 2018: Merkkiteos itä- 
merensuomalaisten esihistorian tutkimuksessa. [Arvio teoksesta Valter Lang: Läänemeresoome tulemised.] - Virittäjä 122 s. 601-607. https://doi. org/10.23982/vir.69835.

Korhonen, Mikno 1993: Kielen synty. Porvoo: WSOY.

LANG, VALTER 2018: Lä̈nemeresoome tulemised. Muinasaja teadus 28. Tartu: Tartu Ülikooli Kirjastus.

Ravila, PaAvo 1959: Kantakieli kielihis- torian peruskäsitteenä. - Virittäjä 63

s. $181-189$.

SArhimaA, Anneli 2018: Ei kannettavu vezi kaivos pyzy. Oikaisuja tietokirjani arvosteluun. - Virittäjä 122 s. 588-592. https://doi.org/10.23982/vir.76336.

YLIKOSKI, JUSSI 2018: The so-called relation forms of nouns in South Saami. A byproduct or remnant of Uralic * $-m p V$ ? - Finnisch-Ugrische Forschungen 64 s. 6-71.

\section{Sosiolingvistinen teoria ja aikamme ilmiöt}

Nikolas Coupland (toim.): Sociolinguistics. Theoretical debates. Cambridge: Cambridge University Press 2016. $458 \mathrm{~s}$.

ISBN 978-1-107-63575-3.

Silloin tällöin opiskelijan kuulee huokailevan, ettei hän ole vielä saanut muodostettua kokonaiskuvaa sosiolingvistiikasta. Tapaan vastata, että enemmän olisin huolissani vastakkaisesta tunteesta - sosiolingvistiikan tutkimuskenttä kun on siinä määrin laaja, että kokonaiskuvan muodostaminen vaatii väistämättä pidempää perehtymistä ja esimerkiksi kotimaista tutkimusta laajemman ja monimuotoisemman tutkimuskentän tuntemusta.

Sosiolingvistisiä lähestymistapoja kieleen ja yhteiskuntaan on käsitelty lukuisissa alan kokoelmissa ja käsikirjoissa, joista osa on keskittynyt erityisesti teoreettisiin ja metateoreettisiin kysymyksiin (esim. Figueroa 1994; Coupland, Sarangi \&
Candlin toim. 2001; Chambers 2009 [1995]; Auer \& Schmidt toim. 2010). Yksittäisen teoksen ei voi olettaa kattavan kuin osan sosiolingvistiikan teorioista ja tutkimuksellisista lähestymistavoista. Tässä arvioitava Nikolas Couplandin toimittama teos Sociolinguistics: Theoretical debates asettuu sosiolingvistiikan teoreettisia kysymyksiä käsittelevien keskeisten teosten joukkoon. Teos sisältää 20 artikkelia, joiden kirjoittajakunta koostuu maineikkaista, teoreetikoinakin tunnetuista sosiolingvisteistä. Teos jakautuu kuuteen osaan, joita esittelen seuraavassa pääosin teoksen etenemisjärjestyksen mukaisesti.

\section{Mistä puhutaan, kun puhutaan teoriasta?}

Teoksen toimittanut Nikolas Coupland sekä aloittaa että päättää kokoelman omilla reflektiivisillä puheenvuoroillaan, 